\title{
Occurrence of pathogenic shrimp viruses in selected wild crab species of Sunderban, India
}

\author{
SANJOY DAS, GOURANGA BISWAS AND TAPAS KUMAR GHOSHAL \\ Kakdwip Research Centre of ICAR-Central Institute of Brackishwater Aquaculture, Kakdwip \\ South 24 Parganas - 743347, West Bengal, India \\ e-mail: sanjoy125@yahoo.co.in
}

\begin{abstract}
Diseases in brackishwater aquaculture systems are the major hindrance to the growth of shrimp industry in India, with white spot viral disease being the most devastating one causing crop failure leading to heavy economic losses. In this study, wild crab species viz., Uca spp. and Sesarma spp., which are frequent dwellers surrounding the shrimp culture ponds, were screened for the presence of white spot syndrome virus (WSSV), infectious hypodermal and haematopoietic necrosis virus (IHHNV) and hepatopancreatic parvovirus (HPV). Out of total 66 samples screened, presence of WSSV and IHHNV was detected in 18.2 and $1.5 \%$ of the samples, respectively. Results of the present study indicate that wild crab species found in and around shrimp ponds could act as carriers of shrimp pathogenic viruses and their effective control is essential for prevention of shrimp viral diseases.
\end{abstract}

Keywords: Sesarma spp., Shrimp viruses, Uca spp., Wild crabs

During 2013-14, India earned ₹3,02,132.6 million through export of fish and fishery products and the contribution of frozen shrimps alone was $64.11 \%$ (₹193683 million) on value basis (MPEDA, 2015). In spite of the tremendous growth of shrimp industry in India, both in terms of domestic and export market, very often diseases of varied etiology cause heavy damage to the industry leading to severe economic losses (Flegel et al., 2008). Among different shrimp pathogens, the white spot syndrome virus (WSSV) is considered as the most important one, which causes heavy crop failure all over the world (Rosenberry, 2001). The main source of WSSV infection in shrimp is the infected broodstock. However presently, the use of specific pathogen free (SPF) broodstock helps to reduce the chances of vertical transmission of WSSV from broodstock. But, the contaminated environment, including water bodies remains a potential source of this viral infection. Different living vectors in and around aquaculture ponds are also responsible for transmission of WSSV to the cultured shrimps (Vijayan et al., 2005). Infectious hypodermal and haematopoietic necrosis virus (IHHNV) and hepatopancreatic parvovirus (HPV) also cause economic losses to the farmers, although the mortality by these diseases is less than that of WSSV (Fauce et al., 2007; Xia et al., 2015). Different species of crabs very often act as carriers of WSSV transmission to cultured shrimps (Meng et al., 2009). The wild crab Uca spp. (fiddler crabs) and Sesarma spp. (marsh crabs) are common dwellers around shrimp culture ponds. WSSV has been experimentally transmitted from these crabs to Penaeus monodon (Kanchanaphum et al., 1998). These crab species are the common inhabitants of intertidal mangrove zones of Asia-pacific region (FAO, 2015). Sunderban is considered as the largest mangrove forest of the world and this region is very important as far as brackishwater aquaculture is concerned. In India, till date, no work has been reported on the study of occurrence of different shrimp pathogenic viruses in these species of crabs. Keeping these in view, the present study was undertaken to examine the occurrence of WSSV, IHHNV and HPV in Uca spp. and Sesarma spp. in Sunderban area of West Bengal.

Crab samples belonging to Uca spp. and Sesarma spp. were collected from different shrimp culture areas of Sunderban, of South 24 Parganas District, West Bengal, India. A total of 66 crab samples (23 samples of Uca spp. and 43 samples of Sesarma spp.) were collected during the period July, 2014 to August, 2015 from different shrimp growing areas of Sunderban. All the samples were collected in individual sterile polypropylene bottles. On arrival to laboratory, the samples were stored at $-40^{\circ} \mathrm{C}$ till processing.

For detection of WSSV, two methods were followed viz., single tube WSSV detection kit (Genei Merck Bioscience, India) and protocol of Lo et al. (1996) for comparison of results. Portions of heart, muscle and gill were collected separately from each crab sample. A total of 
$30 \mathrm{mg}$ of sample (heart, muscle and gill pooled together) were used for extraction of DNA. The tissue was blended in $300 \mu \mathrm{l}$ of DNA extraction buffer (provided with the kit) followed by heating at $95^{\circ} \mathrm{C}$ for $10 \mathrm{~min}$. Then the vials containing blended tissue were centrifuged at $10,000 \mathrm{~g}$ for $10 \mathrm{~min}$ and $2 \mu \mathrm{l}$ from the supernatant was used as PCR template. Another set of samples, consisting of similar type of tissues (heart, muscle and gill pooled together), were processed for WSSV nested PCR (Lo et al., 1996) and IHHNV specific PCR. Tissue processing was done as per the method of Kiatpathomchai et al. (2001) with slight modification. Briefly, $30 \mathrm{mg}$ of tissue was homogenised in a $1.5 \mathrm{ml}$ microcentrifuge tube with $300 \mu \mathrm{l}$ of buffer containing $0.025 \mathrm{~N} \mathrm{NaOH}$ and $0.0125 \%$ sodium dodecyl sulfate, using a sterile micropestle, incubated in a boiling water bath for $10 \mathrm{~min}$ and was placed immediately on ice. The suspension was centrifuged at $10,000 \mathrm{~g}$ for $10 \mathrm{~min}$ and $2 \mu \mathrm{l}$ from the supernatant was used as template for PCR reaction. For preparation of template DNA for detection of hepatopancreatic parvovirus (HPV), $20 \mathrm{mg}$ of crab tomalley was used. Isolation of DNA template was carried out as per the protocol of Manjanaik et al. (2005).

PCR for WSSV using single tube detection kit was carried out in a $30 \mu \mathrm{l}$ reaction volume as per manufacturer's instructions. In PCR assay, three different annealing temperatures $\left(70,58\right.$ and $55^{\circ} \mathrm{C}$ for 5,18 and 25 cycles, respectively) were used, as mentioned in the instruction manual.

WSSV nested PCR was carried out as per the OIE protocol of Lo et al. (1996) with a slight modification using primer pairs 146F1 (5 ${ }^{\circ}$-ACTACTA ACTTCAGCCTATCTAG-3`)/146R1 (5`- TAATGCGGG TGTAATGTTCTTACGA-3') for first step PCR and 146F2 (5`-GTAACTGCCCCTTCCATCTCCA-3')/146R2 (5'-TACGGCAGC TGCTGCACCTTGT-3') for nested PCR. In the first step, PCR was run in a $25 \mu \mathrm{l}$ reaction volume containing $10 \mathrm{pmol}$ of each primer $(146 \mathrm{~F} 1$ and 146R1), 1 U Dream Taq DNA polymerase (Thermofisher Scientific, USA), $200 \mu \mathrm{M}$ of each dNTP, $2 \mu$ of template and $2.5 \mu \mathrm{l}$ of 10x Dream Taq Buffer with $20 \mathrm{mM} \mathrm{MgCl}_{2}$ (final concentration 1x Dream Taq buffer with $2 \mathrm{mM}$ $\mathrm{MgCl}_{2}$ ). Dream Taq buffer also contained $\mathrm{KCl}$ and $\left(\mathrm{NH}_{4}\right)_{2} \mathrm{SO}_{4}$ at a ratio for optimised performance of Dream Taq DNA polymerase as mentioned in the product information. The first step PCR was carried out in a thermocycler (Mastercycler, Eppendorf, Germany) as per Thakur et al. (2002), but the number of total cycles was limited to 30 . In the second step PCR, $2 \mu 1$ of product of first step PCR was used as template. The reaction mixture of second step PCR was similar to that of first step PCR with the primer pair (146F2/146R2) being different. The PCR cycling condition remained same as that of first step PCR, except for the annealing temperature used $\left(65^{\circ} \mathrm{C}\right.$ instead of $\left.55^{\circ} \mathrm{C}\right)$. PCR assay for IHHNV was carried out using the primers 392F (5'-GGGCGAACCAGAATCACTTA-3') and 392R (5'-ATCCGGAGGAATCTGATGTG-3') (Tang et al., 2000; OIE, 2015). The PCR reaction mixture $(25 \mu \mathrm{l})$ used was similar to that of WSSV first step PCR mentioned previously with the exception of primer pair 392F/392R. The amplification was carried out at $55^{\circ} \mathrm{C}$ annealing temperature, using the cycling protocol as mentioned by Tang et al. (2000). Detection of HPV was done by nested PCR (Manjanaik et al., 2005). TheprimersH441F (5'-GCATTACAAGAGCCAAGCAG-3') and H441R (5'-ACACTCAGC CTCTACCTTGT-3') were used for first step PCR (Phromjai et al., 2002; Manjanaik et al., 2005; OIE, 2007). In second step PCR, $2 \mu \mathrm{l}$ of product of first step PCR was amplified using the forward primer 5 '-ATAGAACGCATAGAAAACGCT-3' and reverse primer $5^{\circ}$ - GGTGGCGCTGGAATGAATC GCTG-3' as per Manjanaik et al. (2005). First step PCR was done following the protocol as optimised by Phromjai et al. (2002). The cycling condition as per Manjanaik et al. (2005) was used for second step PCR. The expected sizes of the amplified products were 441 and 265 bp for first and second step PCR, respectively. In each case, electrophoresis of the PCR products along with molecular weight markers was done on $1.5 \%$ agarose gel containing $0.3 \mu \mathrm{g} \mathrm{ml} \mathrm{m}^{-1}$ ethidium bromide in $0.5 \mathrm{x}$ TBE buffer at $6 \mathrm{~V}$ per $\mathrm{cm}$ for $1 \mathrm{~h} 15 \mathrm{~min}$ and was observed and photographed in a gel documentation system (GBOX, Syngene, UK).

Out of a total of 66 samples, 11 samples (6 samples of Uca spp. and 5 samples of Sesarma spp.) were positive for WSSV by single tube detection kit (Genei, Merck Bioscience, India). The infection level in all the positive samples were found to be of 'low' category, as evidenced by the presence of one band of $204 \mathrm{bp}$ with the exception in a sample of Sesarma spp., in which the WSSV level was found to be moderate (presence of two bands of 525 and $204 \mathrm{bp}$ ). Only one sample of Sesarma spp. was found positive to WSSV in the first step of WSSV specific nested PCR using primers 146F1/146 R1, as evidenced by 1447 bp amplified product. However, in the second step PCR, 12 samples including 6 samples of $U c a$ spp. and 6 samples of Sesarma spp. were found positive for WSSV showing 941 bp amplified product. All the 11 samples, which were found positive by single tube WSSV detection kit, were also detected as positive in the WSSV specific two-step PCR. The sample, which was detected positive in first step, was found moderately infected in single tube WSSV detection kit. Out of a total of 66 samples, one sample of Sesarma spp. procured from Kakdwip was found positive to IHHNV, as evidenced by the presence of 392 bp band in PCR using 392F / 392 R primers. However, 
none of the crab samples screened was found positive to HPV in both first step and second step PCR (Table 1).

In this study, presence of WSSV was detected in 12 out of 66 samples tested (18.2\%). Both Uca spp. and Sesarma spp. are found common in brackishwater aquaculture areas of different regions (Kanchanaphum et al., 1998). Though WSSV viral load was found 'low'
The current study showed that the wild crab species (Uca spp. and Sesarma spp.) can carry both WSSV and IHHNV. The presence of HPV was not detected in any of the crab samples tested. But both IHHNV and HPV share common ecological niche and host species. The occurrence of WSSV and IHHNV indicates the risk of presence of HPV, too. Thus, it can be stated that the wild crabs occuring in the brackishwater aquaculture

Table 1. Occurrence of WSSV, IHHNV and HPV in wild crabs (Uca spp. and Sesarma spp.)

\begin{tabular}{|c|c|c|c|c|c|c|}
\hline \multirow[t]{2}{*}{ Crab samples } & \multirow[t]{2}{*}{ No. of samples } & \multirow{2}{*}{$\begin{array}{l}\text { WSSV (detected by single tube } \\
\text { detection kit) }\end{array}$} & \multicolumn{2}{|c|}{$\begin{array}{l}\text { WSSV (detected by nested } \\
\text { PCR, Lo et al., 1996) }\end{array}$} & \multirow[t]{2}{*}{ IHHNV } & \multirow[t]{2}{*}{ HPV } \\
\hline & & & $1^{\text {st }}$ step & $2^{\text {nd }}$ step & & \\
\hline$U c a$ spp. & 23 & $6^{*}$ & 0 & 6 & 0 & 0 \\
\hline Sesarma spp. & 43 & $5^{* *}$ & 1 & 6 & 1 & 0 \\
\hline Total & 66 & $11^{\#}$ & 1 & 12 & 1 & 0 \\
\hline
\end{tabular}

"All six positive samples were of 'low' category (Only one band of $204 \mathrm{bp}$ )

** One positive sample was of moderate category (two bands of 525 and 204 bp) and other four were of 'low' category (Only one band of 204 bp)

\# Ten positive samples were of 'low' category and one sample was of 'moderate' category

in most of the positive samples, and only one sample was positive in first step PCR, there is a potential risk of transmission of those viruses to the cultured shrimp. The samples, which were detected positive by single tube WSSV detection kit (Genei, Merck Bioscience, India), were also detected positive in nested PCR (Lo et al.,1996). However one sample, which was found negative by single tube WSSV detection kit, was detected positive in second step nested PCR. This may be due to the fact that the twostep nested PCR is more sensitive than the single tube detection kit, which uses one sense and three anti-sense primers. However, advantage of single tube detection PCR is that it saves time. In addition to WSSV, one sample of crab was also found to harbour IHHNV as detected by PCR using 392F/392R primers. However, none of the crab samples was found positive to HPV (Table 1).

White spot disease (WSD) caused by WSSV is one of the major limiting factors for the growth of shrimp industry, causing crop loss leading to heavy economic loss. The first dreaded outbreak of WSSV was reported in 1994 in black tiger shrimp, affecting vast areas from Visakhapatnam in Andhra Pradesh to Sirkali in Tamilnadu (Shankar and Mohan, 1998). With the passage of time, WSD affected various farms engaged in brackishwater aquaculture activities in the country and still this disease remains a challenge to the shrimp farmers globally, including India. Although, IHHNV and HPV generally do not cause heavy mortality in commonly cultured shrimp species in India, both diseases cause stunted and slow growth in shrimp leading to production loss (Rai et al.,2009). However, IHHNV causes severe infection in pacific blue shrimp (P. stylirostris) leading to heavy mortality (Bell and Lightner, 1984). sites may act as a potential source of different shrimp viruses, including WSSV, and their effective control is essential for prevention of viral diseases in brackishwater aquaculture systems.

\section{Acknowledgements}

The authors are grateful to the Director, ICAR-Central Institute of Brackishwater Aquaculture, Chennai, India for providing necessary facilities and guidance for carrying out this work. The financial assistance received from the National Fisheries Development Board (NFDB) is also acknowledged.

\section{References}

Bell, T. A. and Lightner, D. V. 1984. IHHN virus: infectivity and pathogenicity studies in Penaeus stylirostris and Penaeus vannamei. Aquaculture, 38: 185-194. doi:10.1016/00448486(84)90142-X.

FAO 2015. Mangrove management. Food and Agriculture Organisation of the United Nations. http://www.fao.org/ forestry/mangrove/3645/en/ (Accessed 21 July 2015).

Fauce, K. A. L., Illiman, J. and Owens, L. 2007. Molecular characterisation of hepatopancreatic parvovirus (Pmerg DNV) from Australian Penaeus merguiensis. Virology, 362: 397-403. doi:10.1016/j.virol.2006.11.033.

Flegel, T.W., Lightner, D. V., Lo, C. F. and Owens, L. 2008. Shrimp disease control: past, present and future. In: Bondad-Reantaso, M. G., Mohan, C. V., Crumlish, M. and Subasinghe, R. P. (Eds.), Diseases in Asian Aquaculture VI. Fish Health Section, Asian Fisheries Society, Manila, Philippines, p. 355-378.

Kanchanaphum, P., Wongteerasupaya, C., Sitidilokratana, N., Boonsaeng, V., Panyim, S., Tassanakajon, A., 
Withyachumnarnkul, B. and Flegel, T. W. 1998. Experimental transmission of white spot syndrome virus (WSSV) from crabs to shrimps Penaeus monodon. Dis. Aquat. Org., 34: 1-7. doi: 10.3354/dao034001.

Kiatpathomchai, W., Boonsaeng, V., Tassanakajon, A., Wongteerasupaya, C., Jitrapakdee, S. and Panyim, S. 2001. A non-stop, single tube, semi-nested PCR technique for grading the severity of white spot syndrome virus infections in Penaeus monodon. Dis. Aquat. Org., 47: 235-239. doi: 10.3354/dao047235.

Lo, C-F, Leu, J. H, Ho, C-H, Chen, C-H, Peng, S-E, Chen, Y-T, Chou, C-M, Yeh, P-Y, Huang, C-J, Chou, H-Y, Wang, C-H and Kou, G-H. 1996. Detection of baculovirus associated white spot syndrome (WSBV) in penaeid shrimps using polymerase chain reaction. Dis. Aquat. Org., 25: 133-141. doi: $10.3354 /$ dao025133.

Manjanaik, B., Umesha, K. R., Karunasagar, I. and Karunasagar, I. 2005. Detection of hepatopancreatic parvovirus (HPV) in wild shrimp from India by nested polymerase chain reaction. Dis. Aquat. Org., 63: 255-259. doi: 10.3354/ dao063255.

Meng, X-H., Jang, I-K., Seo, H-C. and Cho, Y-C. 2009. White spot virus quantification in blue crab Portunus trituberculatus hatchery produced larvae and wild population by TaqMan real time PCR, with an emphasis on the relationship between viral infection and crab heath. Aquaculture, 291: 18-22. doi:10.1016/j.aquaculture. 2009.02.003.

MPEDA 2015. Marine products export crosses US\$ 5 billion in 2013-14. The Marine Products Export Development Authority. http://www.mpeda.com/inner_home.asp?pg= trends (Accessed 4 July 2015).

OIE 2007. Hepatopancreatic parvovirus disease. OIE Aquatic Animal Disease Cards http://www.oie.int/fileadmin/ Home/eng/Internationa_Standard_Setting/docs/pdf/ HepatopancreaticParvovirusCard2007_Revised 92707. pdf (Accessed 30 July 2015).

OIE 2015. Infectious hypodermal and hematopoietic necrosis. OIE Manual for diagnostics tests for aquatic animals. http://www.oie.int/fileadmin/Home/eng/Health_standards/ aahm/current/2.2.02_IHHN.pdf (Accessed 30 July 2015).
Phromjai, J., Boonseang, V., Withyachumnarnkul, B. and Flegel, T. W. 2002. Detection of hepatopancreatic parvovirus in Thai shrimp Penaeus monodon by in situ hybridisation and PCR amplification. Dis. Aquat. Org., 51: 227-232. doi: 10.3354/dao051227.

Rai, P., Pradeep, B., Karunasagar, I. and Karunasagar, I. 2009. Detection of viruses in Penaeus monodon in India showing signs of slow growth syndrome. Aquaculture, 289: 231-235. doi:10.1016/j.aquaculture.2008.12.035.

Rosenberry, B. 2001. World shrimp farming 2000. Shrimp news international, N. 13. San Diego, CA, USA.

Shankar, K. M. and Mohan, C. V. 1998. Epidemiological aspects of shrimp viral diseases in India - a review. J. Aqua. Trop., 13: 43-49.

Tang, K. F. J., Durand, S. V., White, B. L., Redman, R. M., Pantoja, C. R. and Lightner, D. V. 2000. Post-larvae and juveniles of selected lines of Penaeus stylirostris are resistant to infectious hypodermal and hematopoietic necrosis virus infection. Aquaculture, 190: 203-210. doi:10.1016/S0044-8486(00)00407-5.

Thakur, P. C., Corsin, F., Turnbull, J. F., Shankar, K. M., Hao, N. V., Padiyar, P. A., Madhusudhan, M., Morgan, K. L. and Mohan, C.V. 2002. Estimation of prevalence of white spot syndrome virus (WSSV) by polymerase chain reaction in Penaeus monodon post-larvae at time of stocking in shrimp farms of Karnataka, India: a populationbased study. Dis. Aquat. Org., 49: 235-243. doi: 10.3354/ dao049235.

Vijayan, K. K., Raj, V. S., Balasubhramanium, C. P., Alavandi, S. V., Sekhar, V. T. and Santiago, T. C. 2005. Polychaete worms - a vector for white spot syndrome virus (WSSV). Dis. Aquat. Org., 63: 107-111. doi: 10.3354/dao063107.

Xia, X., Yu, Y., Hu, L., Weidmann, M., Pan, Y., Yan, S. and Wang, Y. 2015. Rapid detection of infectious hypodermal and haematopoietic virus (IHHNV) by real time, isothermal recombinase polymerase amplification assay. Arch. Virol., 160: 987-94. doi: 10.1007/s00705-015-2357-7. 